УДК 398.3:2-538(497.742)

https://doi.org/10.55302/MF2180113b

Владимир Боцев

\title{
ОБРЕДОТ КУРБАН ВО СТРУМИЧКО
}

Апстракт: Во текстов се зборува за значењето на обредот курбан во Струмичкиот Регион, за празниците на кои се одржува и верувањата поврзани со него. Целта е да се претстави распространетоста на овој обред и да се истакне неговото значење во обредниот живот на заедниците што го практикуваат.

Клучни зборови: курбан, обред, селска заедница, верување, жртвување.

Од литературата во којашто се даваат податоци за курбаните, но пред сѐ од теренските истражувања извршени од средината на 90-тите години на 20 век, па сѐ до денес, може да се заклучи дека курбаните биле и сѐ уште се значајна алка во традиционалната духовна култура на Македонците. Тие се актуелни, активно се практикувани и претставуваат основна нишка околу којашто се одвива обредниот живот на одредена заедница, најчесто селска, но и градска.

Во историјата на религијата и во теоријата на етнологијата и на социјалната антропологија, принесувањето на крвна жртва до божествата се смета за една од најрудиментарните и најраспространетите религиски постапки за заштитата на поединецот или на групата од разни несреќи, смрт и зла што можат да го/ја снајдат. Крвната жртва претставува обид на човекот да го контролира непредвидливото однесување на божествата, т.е. натприродните сили. Обредите се дефинираат и како религиска практика со чија помош човекот настојува да влијае врз натприродните сили, но и да воспостави мост меѓу „овој“ и „оној свет... “(Lich 1983: 109). Тие имаат цел да ја пренесат општествената порака и на тој начин претставуваат значаен дел од невербалниот систем на комуникација (Prošić 1978: 36). Обредите се едно од средствата за создавање и за одржување на чувствата коишто се нужни за да опстане општеството (Нас̌ 1979b: 13). Тие се дејствија што најнапред треба да се разберат како однесување на групниот идентитет донесен во врска со содржината (Antonijević 1997: 189). Според српскиот етнолог Душан Бандиќ: „обредите не можат да егзистираат ако не се целисходни на потребите, ако не служат за задоволување на потребите на одредена индивидуа или колектив“ (Bandić 1990: 25). Ако обредите траат, тоа е затоа што имаат функција, извршуваат функции (Нас̌ 1979а: 48). Така и обредот курбан кај Македонците, особено во струмичкиот крај, егзистира затоа што задоволува одредени религиски и општествени потреби на оние што го практикуваат. Во контекст на ова е и тврдењето дека причината за опстојување на еден обред треба да се бара во неговата општествена функција.

Во обредите на принесување на крвна жртва Македонците изградиле свој комуникациски систем на знаци. Со овој систем на знаци тие го 
изразуваат својот став за самиот обред, но го изразуваат и својот поглед на светот, правејќки го тоа со експресијата на вербалните и на невербалните знаци, коишто соопштуваат идеи преку пораките што ги испраќаат (Giro 1975: 9). Овие пораки ги изразуваат напорите на заедницата да си обезбеди сигурна егзистенција во периодот што е пред неа, но и придонесуваат за обновување и за потенцирање на обединувачките врски меѓу припадниците на заедницата, пораки што треба да стигнат до неговите учесници, но и пошироко.

Крвното жртвопринесување кај Македонците е нашироко застапено во сите сфери на: обредното живеење, календарските обреди, обредите од животниот циклус на човекот и разните обреди што се преземаат при одредени стопански активности, како што се: стригот на овците, градењето нова куќа, вселувањето во новата куќа и сл., а се движи од принесување на крвна жртва од поединци сѐ до принесување на крвна жртва од заедници, односно таа се практикува во сферата на колективното и на индивидуалното живеење. Обредот кај народот е познат под името курбан, кој буквално значи принесување на крвна жртва (Škaljić 1985: 426).

Струмичкиот Регион изобилува со обреди во кои е застапена крвната жртва, односно сметам дека тој е еден од етнографските региони во Македонија во кој таа се практикува масовно. Во литературата, податоци за курбаните во Струмичко има кај Љ. Зотовиќ, која ни соопштува информации за курбанот во с. Костурино (Зотовић 1958: 151-156), како и кај собирачот и истражувачот на македонската народна култура од Струмица, Иван Котев, кој објавил текстови за курбаните во Струмичко во повеќе списанија (Котев 1979: 79-83; Котев 1992: 187, 193; Котев 2000: 159-172; Котев 2001: 305-314). Кога станува збор за практикувањето на крвната жртва поврзана со календарот, жртвопринесувањето може да се смести во летниот и во зимскиот период од годината.

На Арангеловден (21.11) во селото Стиник се колело вол во црквениот двор. Месото некогаш се варело во казани, но селаните решиле дека тоа е непрактично и сега го раздавале живо: колку гости - толку парчиња. Треба да се спомене дека иселените жители од с. Стиник кои живеат во с. Дражево одат на курбан во Стиник, иако на истиот ден се коле курбан и во с. Дражево (Инф.: Б. К.). Месото од курбанот било за здравје. Оние што не можеле да дојдат на курбанот порачувале од месото. Доколку не дојде поп, тогаш се собираат три жени и го окадуваат месото. „Не бива да не се заколе курбан затоа што тоа е за здравје. Арангел е ден на зимата, да нѐ чува Господ од таа зима и да остане кон нашето царство, да го чува Стиник од лоша зима. Дури и да нема луѓе во селото ќе се коле курбан“ (Инф.: В. К.).

Во с. Дражево, курбан на Арангел се коле затоа што врз селото се струполила лавина. Една година селаните не се сложиле да заколат бик, но на една недела пред празникот повторно се струполила лавина врз селото и од тогаш не се престанало да се коле курбан на тој празник (Инф.: И. 3.). Иако нема постојани жители во селото Бајково, на Св. Арангел иселените одат и колат курбан (Инф.: С. К.).

Значајно место во обредниот календар на Македонците има празникот Илинден, Св. Илија (02.08.). Народот верува дека овој светец престојува во 
облаците, ги отклучува и управува со нив. Се верува дека тој управува и со громовите и светкавиците (Вражиновски 2002: 94, 101). Ваквите верувања на Македонците се одразени и во обичаите на принесување крвна жртва на денот на светецот, на Илинден. Според она што го сретнавме на теренот во врска со жртвувањето на Илинден може да се заклучи дека кај народот постои верување за Св. Илија како господар на изворите, особено оние со голема издашност. Затоа на таквите места се принесува жртва, најчесто крупен добиток: вол, бик или теле. Во селата Мокрино и Смоларе се коле курбан за да не исчезне водата од изворите блиску до селата. Така, во с. Мокрино курбанот - вол, се купува неколку дена пред празникот Илинден и се чува во селската штала. При изборот на животното за курбан се внимавало тоа да е еднобојно, бидејќи „така било поубаво, да не се меша годината, за да тече водата исто, а не пола година да тече, а пола не“. Волот се врзувал до изворот на јаворово дрво, а го колел јак и здрав маж. Колењето на волот се пренесувало од татко на син. Волот го колеле до изворот, така што најголемиот дел од крвта истекувала во водата. Главата на животното ја вртеле трипати околу изворот, така што се внимавало крвта да капе во водата. Овој чин го предводел најстариот член на водната заедница од селото и при тоа велел: „Благодариме на Господа што толку години водата тече и го напојува нашето поле и заради таа чест секоја година на ист ден даваме жртва, вол, за течење на водата““. Попот ја благословувал водата. Членовите на водната заедница од селото го подготвувале месото во казани, коишто секогаш требало да се во непарен број. Сите фамилии од селото имаат одредено место до изворот, каде што седеле секоја година. На празнувањето доаѓале гости од околните села, а имало и пеливани од Штип и Радовиш (Инф.: А. Е.). Во селото се памети дека во 1913 или 1914 година заради војната не се заклало курбан на Илинден. Но, тамошниот воденичар Коста заклал петел и водата се појавила. Наредната година повторно започнале со колење на курбанот. (Инф.: Р. П.).

Во селото Смоларе колеле говедо за курбан на Св. Илија на местото Горна Полјана. Курбанот се колел на изворот за да не престане водата да тече. Во селото имало и други празници на коишто се колел курбан, но тие се напуштени, за разлика од курбанот за Св. Илија што се коле на споменатата локација: „Таму оште не сме оставиле. Јас сум 80 години, не е прекинано“ (Инф.: С. Ј.).

Во верувањата поврзани со жртвопринесувањето на Илинден, мошне впечатлива е улогата на Св. Илија во изведувањето на обичајот. Се верува дека тој раководи со текот на обичајот, но и поставува барања од луѓето кои го практикуваат. За едно од најстарите култни места во Македонија го сметам местото кај големиот даб наречен „крстец“, што се наоѓa над селото Бадилен, а под чија крошна се колел курбан за време на празникот Илинден. Во поткрепа на ова мое мислење ја имам во предвид важноста на дабот во религијата на старите Словени, а со тоа и кај Македонците (Кулишић и др. 
1970: 298)1 , а исто така го имам во предвид и податок од Климент Охридски за уништување на „светото дрво Александар“ од страна на Кирил Филозоф, под кое што дрво се вршело жртвопринесување (Иванова, ред. 1986: 55-56).

Митровден, Св. Димитрија (08.11.) е празник што го означува крајот на летниот период на годината и почетокот на зимскиот. На овој празник се исплатуваат: овчарите, падарите, протогерите, измеќарите и се прават нови договори за следната година (Малинов 2006: 230-231). На овој празник се договара и цената за услугите на селскиот свештеник, како што беше 1995 година во с. Сушица. Во ова село, митровденскиот курбан е времето кога невестите, кои стапиле во брак меѓу два Митровдени, се воведуваат во женскиот дел на селската заедница. Јавно и дефинитивно се прогласуваат за нејзини рамноправни членови, односно им се легализира и им се потврдува новиот статус, придобиен преку свадбата (Христов 2004: 172), и конечно преминуваат од групата на девојките во групата на жените од селото (Lič 1986: 117). Тие го постигнуваат тоа со бакнување на раката на сите жени присутни на курбанот во црковниот двор.

Во Ново Село, пак, на Митровден, покрај тоа што се жртвувал вол во дворот на селската црква, оние што таксале („обештале“) курбан: овца, кокошка и сл., го носат и го оставаат внатре во црквата (ВАММ, к. 2).

Во селото Пиперево, на Св. Никола летен (22.05.) во дворот на црквата се коле вол. Вол за курбан започнал да се коле откако почнале редовно громови да удираат во дел од атарот на селото, каде што се сеело житото. За да престанат да удираат громовите, селаните решиле да колат курбан на Св. Никола летен - „сонено било“. Кога сакале да го заколат курбанот на местото, каде што најчесто удирале громовите, тогашната власт им забранила да го сторат тоа. Затоа, тие решиле курбанот да го колат во црквата, а главата на волот да ја закопуваат на местото, каде што удирале громовите (BАMМ, к. 6).

Курбан се давал и при првото вселување во куќката. Кога се „седнувало“ во куќата курбанот, бело јагне, се колело во оџакот. Се колело за „да не падне, да стое оџако“. Кога се колело се велело: „Со здравје да седнат, со здравје да живеат во неа“. Се канеле и гости на ручек (Инф.: Д. Д.). Во селото Муртино, во новите куќи, кои немале оџак, курбанот се колел на прагот од куќата. Откако ќе се заколело, јагнето се вадело надвор и три пати се заобиколувала куќата, така што крвта капела околу неа. Се колело за да биде живо и здраво cè што ќе се внесе („вкара“) во куќата, како и за здравје на членовите на семејството. Курбанот го колел најстариот - „домакино“, но тој не ја јадел главата, како кај останатите курбани. Прв во куќата влегувал домаќинот

\footnotetext{
1 Дабот бил поврзан со богот на громот. Оттука тој се поврзува со името на двајца светци: Свети Горѓ́ и Свети Илија. На македонска територија дабовите се честа појава, каде што на некои празници, како на Илинден и на Гурѓовден, се собира месното население од околината и се коле курбан, се поднесува жртва. Луѓето се собираат со верба дека дабот има лековита моќ и може да им помогне на болните, а посебно на жените да добијат потомство. Исто така, покрај светите дабови, луѓето во сушните денови се молат за дожд (Вражиновски 2002: 90-91).
} 
стапнувајќи на прагот, а потоа, по старост, влегувале останатите. Секој што ќе влезел морал да касне по малку од јагнето: „Косчичка ке глоднат, ама ке глоднат од това јагне, таа вечер“ (Инф.: Т. К.).

На Гу урѓовден во селото Муртино се колат таксани курбани, односно ветени курбани - за здравје на одреден член на семејството. Главата на курбанот не смеел да ја јаде оној за кој е таксан курбанот (Инф.: Т. К.). На Гурѓовден во ова село се давало курбан, јагне, на првата година од венчавката (Инф.: Р. В.).

Курбаните најчесто ги следи прикаска, легенда или верување, којашто/коешто го оправдува давањето на крвната жртва и го објаснува нејзиното егзистирање низ времето сѐ до наши дни. Ваквите прикаски, легенди и верувања ја изразуваат религиската основа, религискиот мотив за прапочетокот на изведувањето на одредено конкретно жртвопринесување. Непостоењето на религискиот мотив би го довел во прашање значењето на обредот на принесувањето на крвната жртва, односно тој би се свел само на неговата форма (Bandić 1990: 7). Дури и ако за одреден обред на принесување на крвна жртва на прашањето: „Зошто го правите тоа?“, упатено до оние што го практикуваат, добиваме одговор: „Така правеле нашите стари“, религискиот мотив е присутен во верувањето дека тој е така даден, го има, суштествува и нема потреба од коментари (Байбурин 1989: 17).

Иако жртвопринесувањето низ вековите на неговото егзистирање било под силен притисок да се напушти, особено од христијанската црква, во социјалистичкиот период од власта и во последно време од „нивелаторските дејствија на цивилизацијата“" (Обрембски 2002: 69), тоа не исчезна од традиционалната култура на Македонците, туку напротив, зазема важна улога во нивниот религиозен и световен живот (Obrębski 1977: 3). „Светата должност“ за изведување на курбаните и нивното дејство врз натприродните сили, односно нивната религиска основа, најчесто се однесува кон задоволување на следните потреби на индивидуата или заедницата, која ги практикува: за здравје и плодност на мажите, за здравје и плодност на жените, за да не умираат мажите, за да не умираат жените, за заштита, за плодност и за здравје на стоката, за обезбедување дожд, за издашност на изворите, за истерување на болест, за заштита од непријатели, за месото на курбанот како лек, за заштита од град, за заштита од разни несреќи, за среќа, за превентива од несреќи и смрт на работното место, за против уплав, за да не се разболуваат, за преживеана несреќа, за преживеана болест, за заштита од болест, за заштита од гром или „за од гром“, за помен на умрен, за среќно вселување во нова куќа, за да не паѓа новата градба, за вработување и др.

Религиските основи за давање крвна жртва се присутни и во настојувањата на селаните од селото Мокрино да ја задржат издашноста на водата од изворите во близина на селото, со колење на курбан. Тие, секоја година, на Илинден колат вол или бик, така што крвта од жртвата тече во изворот. Веруваат дека ако не се даде жртвата, водата од изворот ќе престанела да тече. Затоа тие, покрај крвната жртва како благодарност при чинот на жртвувањето, ги изговарале и следните зборови: „Благодариме на Господ што толку години водата тече и го напојува нашето поле.“ Селаните, 
течењето на водата, го поврзуваат со волјата на Господ, со нивните надежи преку крвната жртва да ја поттикнат таквата негова волја, и на тој начин да го контролираат сакрумот (Obrębski 1977: 12). Жртвувањето претставува инструмент со кој селаните можат да ја контролираат сферата на сакралното и профаното, преку задоволување на желбите на патронот, во овој случај Свети Илија, примачот на жртвата. Истовремено, течењето на водата, според верувањето на селаните од с. Мокрино, директно е поврзано и со жртвеното животно. Имено, „тоа треба да биде во една боја за да тече водата преку целата година рамномерно, а не пола година да тече, а пола година да не тече“ (Инф.: А. Е.).

Ова подразбира дека ако не се одржи обредот, односно ако не се заколе курбан, тогаш следуваат казни од Господ и од неговите светци. Овие казни упатени од Господ и светците кон „грешното човештво“ особено се чести при напуштање на одредени обреди како што е практикувањето на крвната жртва, курбанот. Затоа тие упатувале три вида казни. Едниот вид казни се однесувале кон нарушување на егзистенцијалните потреби на целата заедница, со насочување на природните сили против заедницата. Вториот вид казни се насочувале кон одредени групи, со предизвикување на зачестени умирања на членови на групата и третиот вид казни е насочен кон поединецот, преку предизвикување лични несреќи.

Црквата извршила големо влијание врз практикувањето на обредите, коишто во себе ја содржат крвната жртва. Основна нејзина цел била и сѐ уште е да ги искорени овие обреди од религиозниот живот на Македонецот. Таквата нејзина намера низ вековите тешко се реализирала. Затоа таа настојува на секаков начин и по секоја цена, колку што е можно повеќе, да го наметне своето учење и гледање врз оние што го практикуваат овој обред и на тој начин, ако не можела радикално, тогаш малку по малку да се наметне врз него, со крајна цел да го потисне и да го избрише од нивната меморија.

Владиката Пимен, додека бил свештеник во с. Водоча, настојувал да ги разубеди селаните да не колат курбани. Ги убедувал, како што рече: „Со арно, со лошо.“ Ги прашувал „каде се гробовите на оние што изумреле во времето кога не се колеле курбани?“. Тој на селаните им ја објаснувал и „генезата“ на курбанот. Имено, според него, „порано кога доаѓале гости во црквата на празниците, луѓето немале пари, па носеле кој што има, јагниња итн. Јагнињата се колеле за да се нахранат гостите, и од тоа со тек на времето се создала традиција да се коле курбан“. Очигледна била намерата на владиката да го десакрализира обичајот на колење на крвна жртва и да го сведе на обично консумирање храна на заедничка трпеза. Исто така, во убедувањата за напуштање на курбанот, владиката ја истакнувал саможртвата на Христос, кој е последната жртва, односно дека тој се принел себеси за жртва и ги прекратил дотогашните жртвувања. Настојувал селаните да ги принесуваат единствените вистински жртви, лебот и виното, односно телото и крвта Христова. Тој, слично како и отецот Кирил Пејчиновиќ, ја доведувал во прашање и припадноста на селаните кон христијанството. Ги прашувал: „Какви сте вие христијани? Го празнувате Св. Димитрија, а не влегувате во црквата, иако се наоѓате во нејзиниот двор, на само неколку метри од неа“. Ги 
убедувал селаните од с. Водоча дека протекувањето на крвта од жртвуваното животно го сквернавело светото место, односно црковниот двор, дека тоа со тој чин не било повеќе свето и за да станело повторно свето, требало да се освети. Убедувањата и настојувањата на владиката за да се престане со колењето на курбани биле насочени и кон употребата на крвта во одредени народни верувања. Така, тој бил против обредот на мачкање, односно ставање на точки од крвта на жртвата на челото на оние за кои бил наменет, односно „обречен“ курбанот, коешто, според народното верување, требало да му обезбеди здравје. Овој обред го карактеризирал како апсолутно нехристијански, како впрочем и колењето на крвната жртва, односно курбанот.

Убедувањата на владиката Пимен, како што истакна тој, му успеале и сега селаните од с. Водоча на Митровден не колат курбан, туку купуваат месо. Со тоа месо тие организираат заеднички ручек иако сѐ уште го употребуваат зборот „курбан“. Ова укажува на тоа дека следниот чекор на владиката ќе биде искоренување од употреба на овој збор, односно зборот „курбан“ да не се врзува воопшто за активностите на МПЦ-ОА. Ваквата интервенција на владиката во традиционалниот систем на обичаи практикуван од страна на селаните од с. Водоча предизвикало поделба на заедницата на два дела. Едната група престанала да оди на курбанот што го организирала другата група, во согласност со традицијата, и започнала да купува месо и да организира заеднички ручек, односно „трпеза на братската љубов“, како што сега црквата љуби и настојува да ги именува заедничките обеди во црковните дворови и на култните места. Сепак, на крајот владиката Пимен истрајал во своите настојувања да се напушти колењето на курбани на Митровден во с. Водоча, со тоа што успеал да ја убеди и другата група да го напушти жртвопринесувањето. Откако се напуштило колењето на курбаните во ова село, црквата на селаните почнала да им помага во организацијата на заедничкиот ручек со тоа што им давала струја итн. Од тука можам да го извлечам заклучокот дека пред тоа црквата им правела пречки на селаните при организација на курбаните, со недавањето струја на пример, како дел од методите и убедувањата на владиката во искоренување на курбаните. Меѓу неговите методи биле и заканите со казни на поповите, кои ке служат служба за време на изведувањето на овие обреди (инф.: Владика Пимен). Генералниот став на МПЦ-ОА за курбаните е тој дека „тие не се компатибилни со христијанството, односно дека Христос е последната жртва дадена за спас на човештвото“. ${ }^{2}$

Од друга страна, пак, во с. Ново Село, во истата Струмичка Парохија, за време на митровденскиот курбан луѓето внесуваа во црквата животни, овци и кокошки, наменети за курбан, додека попот служеше литургија (Боцев, В., филм). Згора на тоа, курбанот што се колел на сретсело (Котев 1979: 81), сега

\footnotetext{
${ }^{2}$ Изјава на Милан Ѓорѓевиќ, професор на Богословскиот факултет во Скопје, во емисијата „Од наш агол“, емитувана на првиот канал на МТВ на 15.04.2012 година.
} 
се коле во дворот на селската црква, каде што се подготвува обредното јадење и се дели на селаните (ВАММ, к. 3).

Овој пример во сѐ е обратен од она за што се залага и дејствува Македонската православна црква во насока на искоренување и на напуштање на курбаните. Тука свештениците не успеале да го забранат ниту внесувањето на животни во црквата. Напротив, нивното внесување во црквата за време на службата претставува нивно индиректно благословување од страна на попот, кој ја држи литургијата. Во Ново Село, курбанот од сретсело мигрирал во црковниот двор, што можеби може да се разбере како обид да се даде христијанска нишка на жртвопринесувањето. Сепак, ваквата постапка ќе беше разбирлива доколку се работеше за простор, којшто не е дефинитивно освоен од црквата. Чинот на пренесување на курбанот од сретсело во црковниот двор, и тоа во скоро време, во основа не се совпаѓа со намерите на црквата, уште од дамнина, да го насочи жртвопринесувањето од сакралниот кон световниот простор.

Во социјалистичкиот период власта презела најразлични мерки за искоренување на обредот на принесување крвна жртва, така што народот бил принуден да се прилагодува на новосоздадените состојби со желба да го зачува и да продолжи да го практикува она во што верува. Неможноста да се заколе курбанот на саканото место, односно забраната од власта, ги принудило селаните од с. Пиперево тоа да го направат на симболичен начин. Така, курбанот што го ветиле да го колат на празникот Св. Никола - летен (22.05.), со цел да се спречи паѓањето громови, селаните од Пиперево не го колат на местото, каде што најмногу удирале (,трештавале“) громовите, како што било „сонено“, туку во црквата. Но, на местото на трештењето на громовите тие ја закопуваат главата на курбанот. Симболиката на колењето на курбанот на саканото место е во раширеното верување дека токму во главата на жртвуваното животно е курбанот, жртвата, со што се потврдува мислењето дека традиционалните содржини многу често се чуваат во трансформирани облици (Pantelić 1989: 29).

Курбаните, покрај тоа што ги изразуваат настојувањата на заедницата да си обезбеди просперитет и општа благосостојба, ја изразуваат и нејзината солидарност, поврзаноста на нејзините членови, нивната меѓусебна комуникација и соработка (Pantelić 1989: 46; Светиева 2005). На овој начин таа се афирмира и се прокламира како хомогена целина. Ваквата афирмација и прокламација на заедницата во времето на изведувањето на курбанот, односно во моменти кога над неа се надвиснати разни опасности (суша, поплави, зачестени умирања на членови на заедницата и сл.) и ѝ се заканува криза, ѝ помага да ја преброди кризата и да ги потисне негативните тензии што можат да се јават во тој период и деструктивно да влијаат врз нејзината кохезија. Чувството дека не си сам во кризни моменти го зајакнува моралот и го растерува стравот (Петровић 1984: 24-25).

Преку овие обреди селската заедница, на некој начин, со партиципација на нејзините членови во нив, воспоставува еден вид самоконтрола (Obrębski 1977: 12). Партиципацијата на членовите на заедницата во обредот претставува можност и за афирмирање и за манифестација на општествените 
вредности врз коишто се потпира таа. Обредот ги потсетува членовите на заедницата на тие општествени вредности и истовремено ги принудува да им се потчинуваат (Prošić-Dvornić 1982: 48). Тој, исто така, служи да го потсети поединецот на колективните идеали и да ја возобнови општествената кохезија (Gidens 1996: 88-90). Од исполнувањето на овие услови зависел опстанокот и функционирањето на заедницата, така што таа се стреми да ги одржува обредите, а со тоа да го потврди и да го продолжи своето егзистирање, дури и во случаи кога членовите на заедницата го имаат напуштено родното село, односно кога во него не живее никој. Се обидува да го спречи дефинитивното нејзино дезинтегрирање, макар функционирала само еден до два дена во годината, како што се примерите од с. Стиник и с. Бадилен. Постојаното одржување на обредите на принесување крвна жртва овозможува гарантирање на егзистенционалните потреби на заедницата и постојано реафирмирање и потврдување на групното единство, семејните врски, роднинските врски, соседските врски, пријателските односи, личниот идентитет, локалниот идентитет и националниот идентитет.

\section{ЛИТЕРАТУРА}

\section{Кирилични изданија}

Антонијевић, Д. 1997. Дромена. Посебна издања, књ. 72. Београд: Балканолошки институт САНУ.

Байбурин, А. 1989. „Мястото и ролята на ритуала в традиционната култура““. Бьлгарарска еӣног̄рафия, книга 3-4. София: Етнографски институт с музей, БАН.

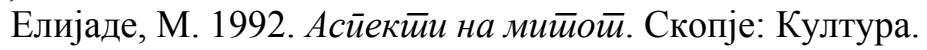

Зотовић, Љ. 1958. „Ритуално клање бика као остатак античког култа плодности“. С̄̄аринар, књ. VII-VIII. Београд: Археолошки институт, САН.

Иванова, К. (ред). 1986. „Похвала за нашия блажен отец и славянски

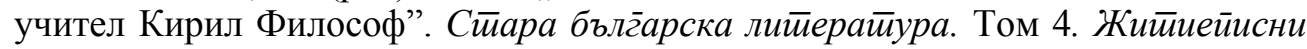
йворби. Съставителство и редакция: Климентина Иванова. София: Български писател.

Котев, И. 1979. „Митровденскиот курбан во с. Ново Село и во неколку други села од Струмичко“. Макеоонски фолклор, бр. 23. Скопје: Институт за фолклор „Марко Цепенков“, 79-83.

Котев, И. 1992. „Светоилијскиот курбан во село Мокрино, Струмичко“. Eйнолог, бр. 2. Скопје: Здружение на етнолозите на Република Македонија, $183-187$.

Котев, И. 2000. „Овчарскиот празник во с. Самоилово, Струмичко“. Макеgонски фолклор, бр. 56-57. Скопје: Институт за фолклор „Марко Цепенков“", 159-172.

Котев, И. 2001. „Култните камења во минатото и во мугрите на новиот милениум во Република Македонија“. Макеоонски фолклор, бр. 58-59. Скопје: Институт за фолклор „Марко Цепенков“, 305-315. 
Кулишић, Ш., Ж. Петровић и Н. Пантелић. 1970. Срӣски мийолошки речник. Београд: Нолит.

Малинов, 3. 2006. Траяицискиот̄ нарояен каленоар на Шойско-

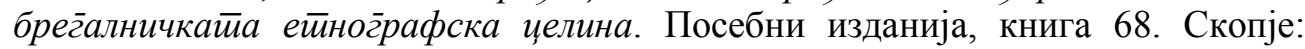
Институт за фолклор „Марко Цепенков“.

Обрембски, J. 2002. Макеgонски ейносоциолошки сӣууии, книга 2. Скопје - Прилеп: Матица македонска и Институт за старословенска култура.

Петровић, Ђ. 1984. „Народ, власт, црква и непогоде“. Макеоонски фолклор, бр. 34. Скопје: Институт за фолклор „Марко Цепенков“, 17-25.

Светиева, А. 2005. Селойо во Макеgонија како ойшйесиивена, економска и обреяна заеяница. Скопје: Институт за етнологија и антропологија, ПМФ, УКИМ [ракопис (скрипта) од предавањата за предметот Социјална култура на Македонците, за студентите на постдипломски студии].

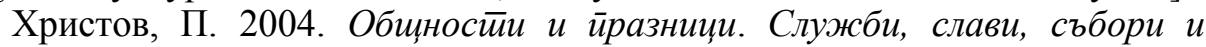
курбани в южнославянскойо село йрез йървайа йоловина на ХХ век. София: Етнографски институт с музей, БАН.

\section{Латинични изданија}

Bandić, D. 1990. Carstvo nebesko i carstvo zemaljsko. Ogledi o narodnoj religiji. Beograd: XX vek.

Gidens, E. 1996. Dirkem. Beograd: XX vek.

Giro, P.1975. Semiologija. Beograd: XX vek.

Hač, E. 1979a. Antropološke teorije, knj. 1. Beograd: XX vek.

Hač, E. 1979b. Antropološke teorije, knj. 2. Beograd: XX vek.

Lič, E. 1983. Kultura i komunikacija. Beograd: XX vek.

Pantelić, N. 1989. „Tradicija u savremenim srodničko-susedskim porodičnim odnosima zapadnoj Srbiji“. Etnoantropološki problemi, sv. 6. Beograd: Odeljenje za etnologiju i antropologiju Filozofskog fakulteta.

Prošić, M. 1978. „Teorijsko-hipotetički okvir za proučavanje poklada kao obreda prelaza“. Etnološke sveske, br. 1. Beograd: Etnološko društvo SR Srbije, 3350 .

Prošić-Dvornić, M. 1982. „Pogrebni rituali u svetlu obreda prelaza, na primeru Stonskog primorja“. Etnološki pregled, br. 18. Beograd: Savez etnoloških društava SFRJ, 41-53.

Škaljić, A. 1985. Turcizmi u srpskohrvatskom - hrvatosrpskom jeziku. Sarajevo: Svjetlost.

\section{Сајтографија}

Obrębski, J. 1977. „Ritual and Social Structure in a Macedonian Village“. Program in Soviet and East European Studies. Occasional Papers, No. 1. Amherst MA, USA: University of Massachusetts, International Area Studies Programs. https://www.yumpu.com/en/document/read/22504371/obrembski-jozef-ritual-andsocial-structure-in-a-macedonian-village [Пристапено на 25.9.2021]. 


\section{Архивски материјали}

и 6.

(BАММ) Видеоархив на Музејот на Македонија - Скопје, касети бр. 2, 3

\section{Филм}

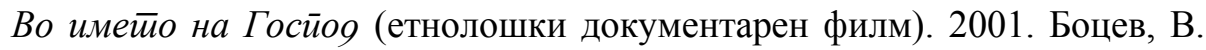
(режија и сценарио). Скопје: Музеј на Македонија.

\section{Интервјуа}

Благоја Китанов (информатор, роден 1930 год. во с. Стиник) во разговор со авторот при теренските истражувања во Струмичко, реализирани во 1998 год. (личен запис).

Ване Китанов (информатор, роден 1968 год. во с. Борисово) во разговор со авторот при теренските истражувања во Струмичко, реализирани во 1998 год. (личен запис).

Илинка Златанова (информатор, родена 1938 год. во с. Стиник, живее во c. Дражево) во разговор со авторот при теренските истражувања во Струмичко, реализирани во 1998 год. (личен запис).

Стојан Китановски (информатор, роден 1950 год. во с. Бајково) во разговор со авторот при теренските истражувања во Струмичко, реализирани во 1998 год. (личен запис).

Ацо Ефтимов (информатор, роден 1968 год. во с. Мокрино) во разговор со авторот при теренските истражувања во Струмичко, реализирани во 1998 год. (личен запис).

Ристо Петров (информатор, роден 1968 год. во с. Мокрино) во разговор со авторот при теренските истражувања во Струмичко, реализирани во 1998 год. (личен запис).

Симеон Јанчев (информатор, роден 1920 год. во с. Смоларе) во разговор со авторот при теренските истражувања во Струмичко, реализирани во 1998 год. (личен запис).

Душанка Делиоска (информатор, родена 1921 год. во с. Двориште, Беровско, живее во с. Муртино) во разговор со авторот при теренските истражувања во Струмичко, реализирани во 1998 год. (личен запис).

Трајанка Колева (информатор, родена 1942 год. во с. Муртино) во разговор со авторот при теренските истражувања во Струмичко, реализирани во 1998 год. (личен запис).

Роска Велкова (информатор, родена 1914 год. во с. Муртино) во разговор со авторот при теренските истражувања во Струмичко, реализирани во 1998 год. (личен запис).

Владика Пимен (епископ на Европската епархија на МПЦ-ОА) во разговор со авторот на 20.10.2010 година во Скопје, во Музејот на Македонија (пишани белешки на авторот). 
Vladimir Bocev

\section{THE RITUAL „KURBAN“ IN THE STRUMICA REGION}

\section{Summary}

From the literature which provides data on the ritual of offering a blood sacrifice, „kurban“ but above all from field research conducted from the mid-90s of the $20^{\text {th }}$ century until today, it can be concluded that „kurbans“ were and still are an important link in the traditional spiritual culture of the Macedonians. They are current, actively practiced and represent a basic thread around which the ritual life of a certain community takes place, mostly rural and urban.

In the Strumica region, the „kurban“ is one of the most significant rituals practiced by the local population. 


\section{ПРИЛОЗИ}

\section{Фотографии}

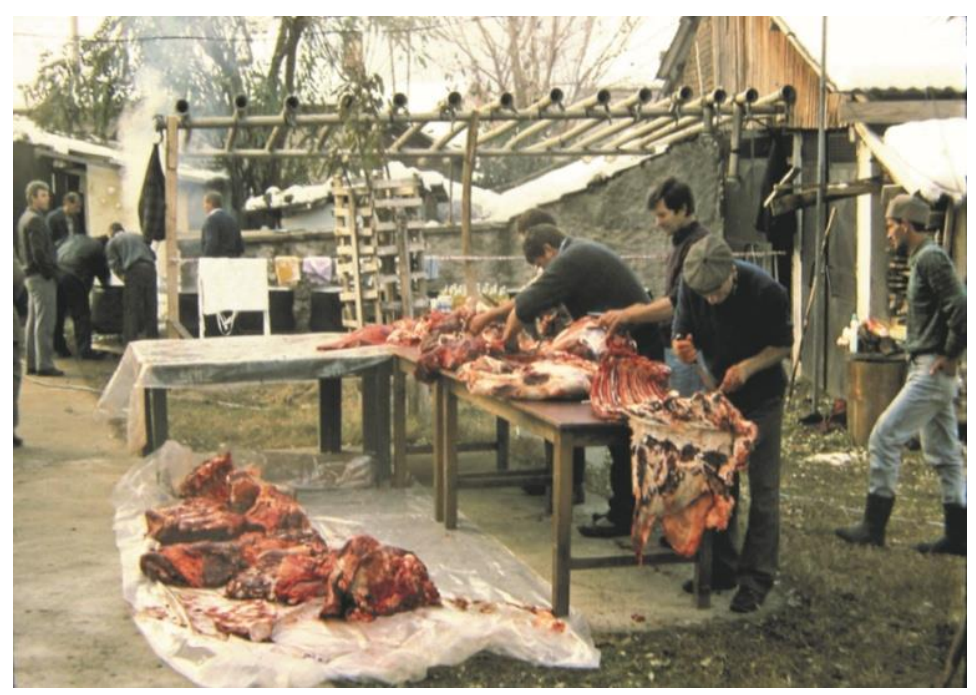

Приготвување на месото од закланиот вол - курбанот за заедничкиот сакрален ручек на Митровден (8 ноември) 1995 година, во Ново Село, Струмичко

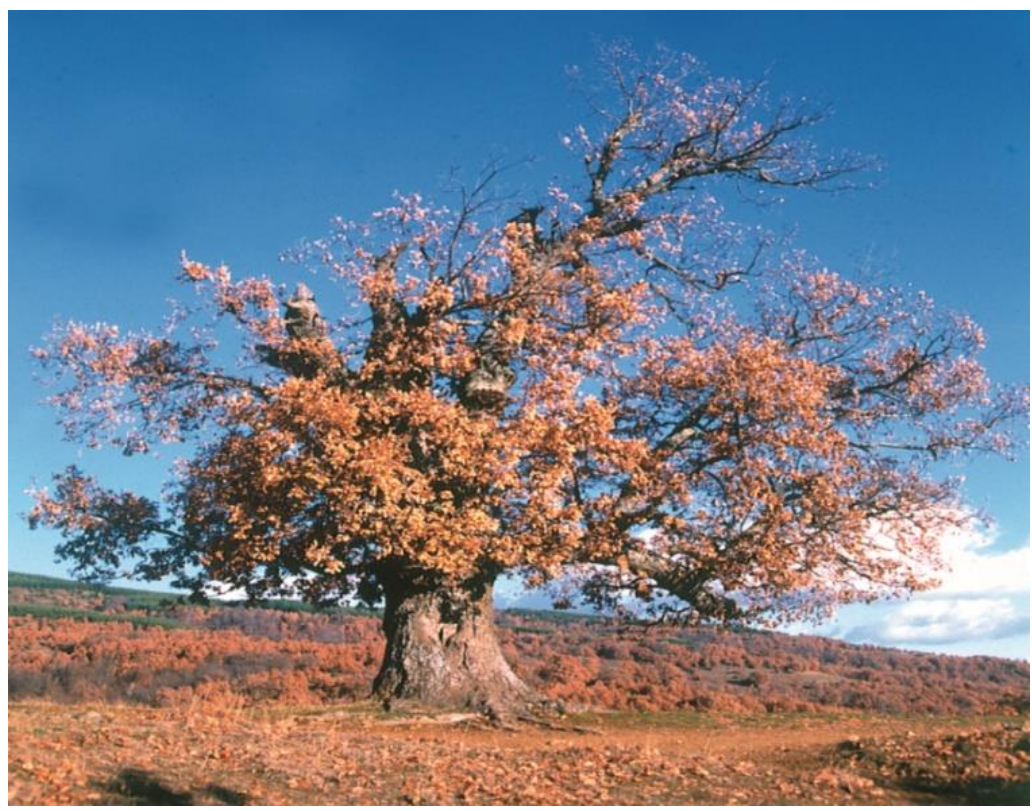

Култното дрво - дабот „крстец“ над с. Бадилен, каде што се принесува крвна жртва (курбан) на празникот Свети Илија (Илинден). 